\title{
REGIONAL INTER-MANAGERS COMMISSION: LOCAL SPACE FOR AGREEMENT AND INTER-FEDERATIVE ARTICULATION?
}

\section{ORIGINAL ARTICLE}

SANTOS, Nadja Romeiro dos ${ }^{1}$, COTA, Ana Lídia Soares²

SANTOS, Nadja Romeiro dos. COTA, Ana Lídia Soares. Regional inter-managers commission: local space for agreement and inter-federative articulation? Revista Científica Multidisciplinar Núcleo do Conhecimento. Year 06, Ed. 09, Vol. 03, pp. 173-189. September 2021. ISSN: 2448-0959, Access Link: https://www.nucleodoconhecimento.com.br/technology-en/inter-managers-

commission, DOI: 10.32749/nucleodoconhecimento.com.br/technology-en/intermanagers-commission

\section{ABSTRACT}

The Regional Intermanagers Commission (CIR) configures the space for agreement, articulation, cooperation and strengthening of the health region. The aim of this study was to reflect on the normative provisions that underlie the construction of the commission as a place of consolidation of regional management attenuating interfederative conflicts. Having as a guide question: how do the Regional InterManagement Commissions provide local spaces of agreement and interfederative articulation? Qualitative study, based on documentary research, based on the analysis of the resolutions of the Regional Inter-Management Commissions of Alagoas, corresponding to the period from 2017 to 2019, using Decree 7.508/11 as a reference standard. The results were organized into four categories: Regional Health Planning; organization of health care actions and services: health region; Federalism,

\footnotetext{
${ }^{1}$ Doctoral student at the Graduate Program in Society, Technologies and Public Policy. Tiradentes University Center (UNIT).

${ }^{2} \mathrm{PhD}$ in Pediatric Dentistry, Professor at the Dentistry Course and at the Graduate Program in Society, Technologies and Public Policies (UNIT/AL) Tiradentes University Center.
}

RC: 98469

Available in: https://www.nucleodoconhecimento.com.br/technology-en/inter- 
CIR and the financing of health services; governance and CIR: channel of negotiation and decision between municipal managers and the State within the Health Region. The Regional Inter-Management Commissions develop significant work in the discussions of regional policies, being a fundamental tool for strengthening governance in the territories, by negotiating the allocation and distribution of resources, essential for planning, interfederative pacts, and health financing, playing a key role for the regional health system of Alagoas, democratic, political and cooperative space.

Keywords: Regionalization, Health Management, Unified Health System, Federalism, Health Policy.

\section{INTRODUCTION}

Brazil's Health Policies have been formulated in order to comply with article 196 of the Federal Constitution (CF/1988), based on public health actions and services that are part of a regionalized and hierarchical network, constituting a single system (SUS), organized according to various guidelines, including decentralization, comprehensive care and community participation (Article 198) (BRASIL, 1988).

A major advance in this sense was the regulation of the Organic Health Law (Law 8.080/90) through Federal Decree No. 7,508 published in July 2011 considered the regulatory framework densifying the constitutional and legal provisions related to the realization of the fundamental right to health in Brazil, nodits regarding the decentralization of public health, with the organization of the SUS, the planning of health care actions and interfederative articulation.

One of the main achievements refers to the operationalization of the SUS within the regional territory, from the validation of the spaces of agreement and deliberation, with a view to the definition of shared management rules, called Regional InterManagement Commissions (CIR), being the process of decentralization of public

RC: 98469

Available in: https://www.nucleodoconhecimento.com.br/technology-en/inter- 
health, one of the constitutional premises, intensifies with the legitimation of regional spaces of agreement.

This political-administrative process of the SUS in Brazil, a victorious model in the National Constituent Assembly (1986-1988), was the consectarian of one of the main demands of the Movement for Sanitary Reform, built due to the various criticisms of the centralizing model then in force in the country, executed at the time by the National Institute of Social Security Medical Assistance (INAMPS).

This organizational principle was also incorporated into the other public policies instituted, especially health, education and social assistance, which, in mutual articulation, structure the bases of a State of social protection.

According to Wagner (2006), decentralization tends to produce a decision-making autonomy in relation to health for federated entities. The increasing financial centralization of the State, along with the continued exercise of fiscal regulation of states and municipalities, and a decisive role in policy formulation produced a combination of state centralization, with decentralizing sectoral policies that, in the case of health, were always dependent on federal induction (VIANA et al, 2002).

The region is understood to be the continuous geographical space, formed by clusters of neighboring municipalities, defined from the existence of cultural, social and economic identities and others, aiming to integrate, organize, plan and execute health actions and services (BRASIL, 2011).

It is in this environment that the CIRs stand out as instruments to support the implementation of health policies in federative regions. In practice, they function as instances of regional governance of health care networks, whose action is relevant to effect the dynamics of regionalization, identify problems, define priorities and propose solutions for their organization, assisting in the constitution of shared objectives and

$\mathrm{RC}: 98469$

Available in: https://www.nucleodoconhecimento.com.br/technology-en/inter- 
in the establishment of a logic focused on the well-being of the population and in the provision of health services.

It is in the context of maintaining municipal protagonism, and strengthening the relations of interdependence and sanitary co-responsibility between the state and municipal entities, that the CIR arises, having as mission the management of the Regional Health Policy, based on the knowledge of the epidemiological and socioeconomic reality of the neighboring municipalities.

With regard to the state of Alagoas, the CIR coordinate the construction of the Regional Care Network (RAR), ensuring the population's access to health services regulating, monitoring and evaluating the goals established for the municipalities inserted in their area.

Therefore, this article aims to reflect on the normative provisions that underlie the construction of CIR as spaces for consolidation of regional management attenuating interfederative conflicts, analyzing regionalization in the SUS, seeking to verify the influence of intergovernmental cooperation in strengthening this strategy. To support the proposed analysis, theoretical references on the theme were reviewed, starting from the overview of the fundamentals of federalism, the SUS in the Brazilian federative structure, and the concepts of decentralization and regionalization, ending with the discussion of some critical factors. In view of the above reflections, the following question arose: how do the CIR provide local spaces of agreement and interfederative articulation?

\section{METHODOLOGY}

This is a descriptive and exploratory study with a qualitative approach, carried out through a thematic review and analysis of the content of the official documents of the $\mathrm{CIR} / \mathrm{AL}$, as a space for agreement and interfederative articulation of the SUS,

$\mathrm{RC}: 98469$

Available in: https://www.nucleodoconhecimento.com.br/technology-en/inter- 
allowing to aggregate knowledge about the object studied, also analyzing the progress of public health policies from the regionalization process (MINAYO, 2010).

We analyzed the resolutions elaborated by the CIR, corresponding to the period 2017 to 2019, available to the public on the page of the Official Gazette of the State of Alagoas (DOE/AL) http://www.imprensaoficial.com.br/diario-oficial, using Decree $7.508 / 11$ as a reference standard. The findings were systematized into four analytical categories, grouped after reading the documents, whose findings are arranged in Table 1, that is: planning (Category 1); organization (Category 2); (Category 3) and governance (Category 4).

\section{RESULTS}

Of the total of 192 resolutions read, an analytical framework was generated (Table 1), which ordered the main deliberations of the CIR and its respective meaning, as relevant contents of the previously elected categories, to guide the discussion.

Table I: Characterization of resolutions by categories of analysis for the period 20172019.

\begin{tabular}{|c|c|c|}
\hline Category & $\begin{array}{l}\text { Sense of } \\
\text { Deliberation }\end{array}$ & Main Deliberations \\
\hline \multirow[t]{3}{*}{ Planning } & \multirow{3}{*}{$\begin{array}{l}\text { Cooperation } \\
\text { strategies } \\
\text { contributing to the } \\
\text { agreement, } \\
\text { ensuring access to } \\
\text { health services to } \\
\text { the population. } \\
\text { Strategy that favors } \\
\text { quality to the }\end{array}$} & $\begin{array}{l}\text { Approves goals proposed by the technical } \\
\text { areas of the State Department of Health - } \\
\text { SESAU referring to interfederative indicators } \\
\text { for the period } 2017-2021\end{array}$ \\
\hline & & $\begin{array}{l}\text { Approves Health Planning, health care and } \\
\text { interfederative articulation }\end{array}$ \\
\hline & & $\begin{array}{l}\text { Approves State Plan for Humanization of } \\
\text { Health of the State of Alagoas, four-year } \\
2016-2019 \text { and the Operating Plan } 2017\end{array}$ \\
\hline
\end{tabular}

$\mathrm{RC}: 98469$

Available in: https://www.nucleodoconhecimento.com.br/technology-en/inter- 


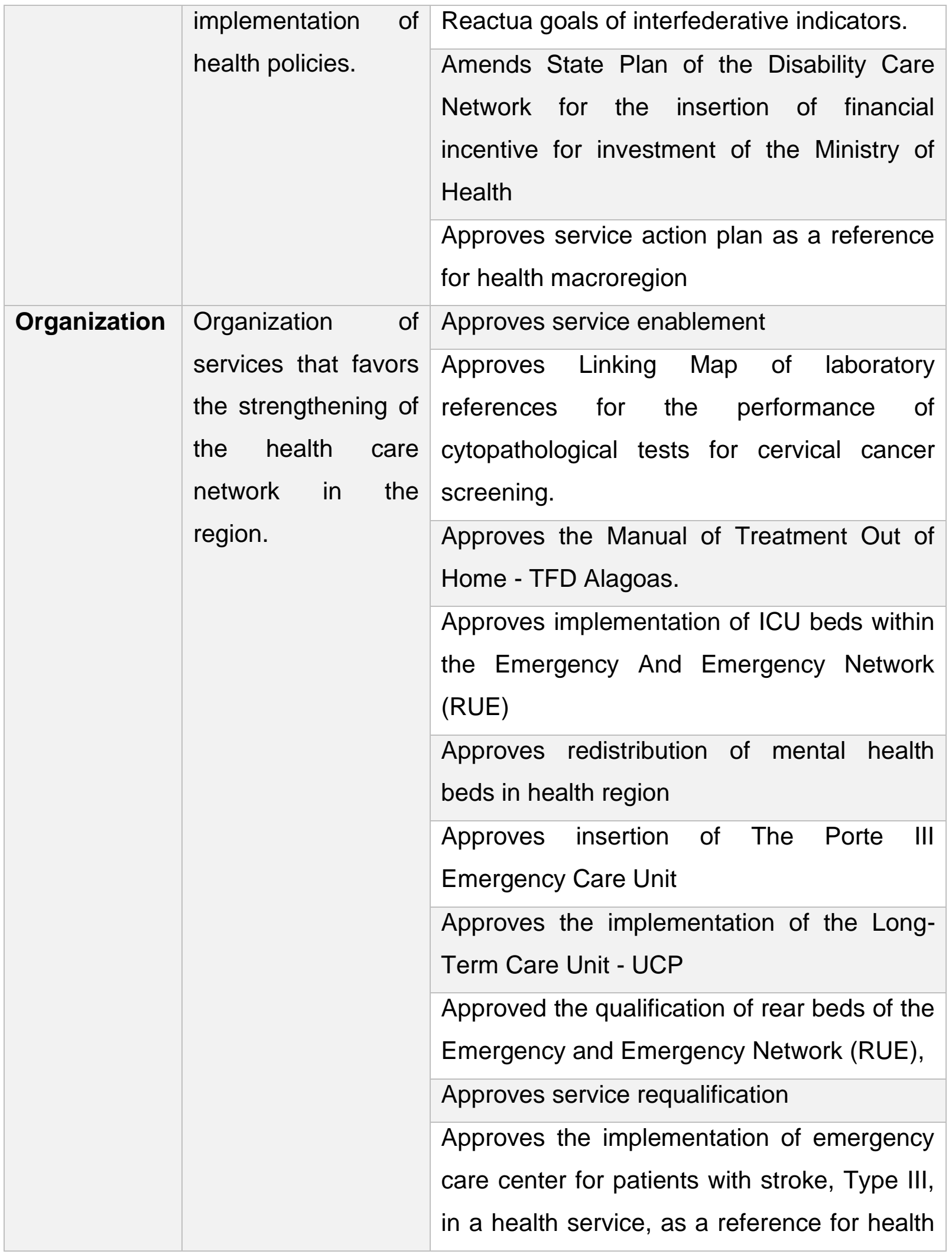

RC: 98469

Available in: https://www.nucleodoconhecimento.com.br/technology-en/inter- 


\begin{tabular}{|c|c|c|}
\hline & & region \\
\hline & & $\begin{array}{l}\text { Approves the change of the specialty of the } \\
\text { Entrance Door of Clinical Urgency service. }\end{array}$ \\
\hline \multirow[t]{7}{*}{ Financing } & \multirow{7}{*}{$\begin{array}{l}\text { Strategy for } \\
\text { financing and } \\
\text { encouraging } \\
\text { regionalization. } \\
\text { Implementation of } \\
\text { public policies in the } \\
\text { region. }\end{array}$} & $\begin{array}{l}\text { Approves relocation of physical and financial } \\
\text { ceilings in agreed and integrated } \\
\text { programming }\end{array}$ \\
\hline & & $\begin{array}{l}\text { Financing and transfer of federal resources - } \\
\text { Emergency And Emergency Care Network }\end{array}$ \\
\hline & & $\begin{array}{l}\text { Approves the relocation of financial resource } \\
\text { for the transfer of the SUS of the Block of } \\
\text { Costing of Public Health Actions and } \\
\text { Services of the municipality, referring to the } \\
\text { use of physical and financial ceilings } \\
\text { according to agreed and integrated } \\
\text { programming of medium and high complexity } \\
\text { care (Ambulatory and Hospital MAC) }\end{array}$ \\
\hline & & $\begin{array}{l}\text { Approves the request for an increase in the } \\
\text { financial resources of Medium and High } \\
\text { Ambulatory and Hospital Complexity (MAC) } \\
\text { of the municipality. }\end{array}$ \\
\hline & & Strategies and Compensation - FAEC for the \\
\hline & & $\begin{array}{l}\text { Annual Financial Limit Component of } \\
\text { Outpatient and Hospital Care of Medium and } \\
\text { High Complexity - MAC of the States, the } \\
\text { Federal District and the Municipalities; }\end{array}$ \\
\hline & & $\begin{array}{l}\text { Approves financial limits to be made } \\
\text { available to the municipality, destined to the } \\
\text { cost of elective CIRúrgicos procedures, } \\
\text { which will refer to the Health Region. }\end{array}$ \\
\hline
\end{tabular}

RC: 98469

Available in: https://www.nucleodoconhecimento.com.br/technology-en/inter- 


\begin{tabular}{|l|l|l|l|} 
Governance & $\begin{array}{l}\text { Government } \\
\text { strategies to } \\
\text { strengthen regional }\end{array}$ & Regional Intermanagers Commission \\
governance and & Intermanagers Commission. \\
improve \\
communication \\
networks, \\
$\begin{array}{l}\text { contributing to the } \\
\text { integrality of } \\
\text { federative actions. } \\
\text { Support of shared } \\
\text { management. }\end{array}$
\end{tabular}

Source: Own authorship, 2020

\section{DISCUSSION}

\subsection{REGIONAL HEALTH PLANNING}

Planning is a permanent and dynamic process, and should also include emergency situations considered in the short term. In the health area, planning is the competence of the three spheres of Government and forms the basis for the execution, monitoring, evaluation, control and management of the health system, assuming knowledge of the existing reality and the instruments available and necessary to achieve the proposed goals.

According to Santos (2017) the absence of planning harms the organization of health services, weakening cooperation and coordination of regionalization policy. In fact, the Federal Constitution, in its art. 176, determines that it is mandatory planning for the public power and inducer for the private sector (BRASIL, 1988).

RC: 98469

Available in: https://www.nucleodoconhecimento.com.br/technology-en/intermanagers-commission 
The process of regionalization of health allows the allocation of services in the health network, in order to contemplate all levels of health, according to the needs of individuals. The documents analyzed in this research demonstrated that planning has become an important agenda in the discussion agendas of managers in health regions.

One of the consequences of planning is to provide clarification of the responsibilities of the three spheres of government, the definition of the provision and management of services and the contribution of financial resources. In this way, the planning and budgeting process must be indivisible. Thus, budget programming in health is essential, as an integral part and detailof health plans (BRASIL, 2011).

According to Duarte and other collaborators (2018) the organization of the planning and budget of the SUS is ascending, integrated carried out in a regionalized way, from the recognition of the health problems of each municipality, built through the articulation between autonomous entities, in order to ensure the quality of life of the population, through the organization of health services. In practice, the planning and organization of the activities of each level of direction of the SUS will be ascendant, guided by the health needs of the population, through the organization of the health plan in each jurisdiction, where its financing is provided for in the budget proposal (BRASIL, 1990).

The integrated regional planning establishes the CIR as a space for articulation, negotiation and agreement between the signatory entities, allowing the identification, definition of priorities and negotiation of solutions for the organization of a regional network of actions and services of integrated and resolutive health care according to the principles of the SUS (BRASIL, 2011).

The CIR has the importance of consolidating public health policies, through the monitoring of the Integrated Agreed Programming, in order to favor the construction of the regulatory design, with definition of flows and protocols with a view to the

RC: 98469

Available in: https://www.nucleodoconhecimento.com.br/technology-en/inter- 
qualification of social control and organization of shared management in an ascending way, planned with definition of financial and administrative resources that contribute to regionalization (BRASIL, 2011).

The results of the documentary analysis show that the CIR is a space with potential to develop institutional capacity, for regional territorial planning and coordination, aimed at overcoming corporate interests and creating a local governance based on co-management and democratization of intergovernmental decision and cooperation.

\subsection{ORGANIZATION OF HEALTH CARE ACTIONS AND SERVICES: HEALTH REGION}

The analysis of the resolutions of the CIR shows that the organization of health care is a constant "stage" of discussion in the federative spheres, evidencing that health care networks are the direction for the work of agreement within the Intermanagement Commissions (BRASIL, 2011).

The organization of health services should be contemplated in the health regions, which constitute a continuous geographical space, incorporated by a cluster of municipalities, constituted as a territorial basis for planning health care, which results from the shared region of regional financing through the execution of services aimed at governance in the region, through cooperation between federative entities; should contain actions of primary care, psychosocial care, health surveillance, emergencyemergency, specialized outpatient and hospital care (BRASIL, 2011).

For the integration of public health actions and services in a regionalized network, it is necessary that the federated entities work in an integrated way.

This aggregation of services in the region is necessary to ensure the integrality of care, through the flow of reference and counter-reference, and it is up to the larger manager to answer, in the region, for services of greater complexity, which require

RC: 98469

Available in: https://www.nucleodoconhecimento.com.br/technology-en/inter- 
scale and other administrative and technological components, which can be accessed by municipalities of other federated entities (ANDRADE; FRANCISCHETTI, 2019).

According to Santos (2017) the cooperation between the instances of agreement in the territory as a way of organizing the spaces of operation of the SUS, is a key point given its sanitary, technological and financial singularity is fundamental in the structuring of the SUS. Without this organizational format, the health system was not able to provide comprehensive, equal and decentralized care.

As a way of organizing and integrating this network of services within the territory, the signatories assume the responsibility established in the Organizational Contract of Public Action (COAP), with the purpose of ensuring health actions and services in a regionalized and hierarchical manner, with definition of executive, budgetary, financial and control of evaluation defined between States, Municipality and Union, establishing health goals for costing and investment that guarantee full care to the population (BRASIL, 1990, 2010, 2011; SANTOS, 2017).

The decision to qualify health care and management involves technical, ethical and cultural aspects, with the need to comply with the cooperative political pact between the management bodies of the system, expressed by a "fine association of technique and policy", to ensure the investments and resources necessary for change (BRASIL, 2010, 2011).

The solution is to innovate the process of organization of the health system, reordering actions and services in the development of regionalized Health Care Networks (RAS), to produce a positive impact on the population's health indicators.

The SUS Management Pact establishes the need to design RAS, organized in the territories of health regions, which is the privileged space for the construction of

$\mathrm{RC}: 98469$

Available in: https://www.nucleodoconhecimento.com.br/technology-en/inter- 
agreed responsibilities and allows the integration of policies and programs through the joint action of the federal, state and municipal levels (BRASIL, 2010).

Decree 7508/11, in Chapter II, defines that the SUS must be formed by a regionalized and hierarchical network, and that its health regions should be organized to offer health services articulated at levels of increasing complexity, with the purpose of ensuring comprehensive care and health care (BRASIL, 2001).

The Pact established the regional space as a privileged place for the construction of the agreed responsibilities, requiring the fulfillment of the responsibilities assumed and agreed goals, and each sphere of government is co-responsible for the management of the set of policies, with explicit responsibilities (BRASIL, 2006).

The results clearly show the organization of health services by care networks and federative agreements for the execution of services, contemplating the needs of health regions. According to Santos (2017) it is necessary to act in an integrated and systemic way sharing competence flexibly, aiming to ensure agreement between federative entities, which influence the health of the population, promoting intersectoriality, capable of reducing social inequalities.

\subsection{FEDERALISM, INTER-MANAGEMENT COMMISSIONS AND THE FINANCING OF HEALTH SERVICES}

Federalism is a form of organization of the State that was born from the dialectical balance between centralization and decentralization of political power, corresponding to the need to maintain unity in diversity, without concentrating power in a single nucleus, nor pulverizing it (DOURADO; ELIAS, 2011).

According to Curvina (2017), federalism emerged in 1787, with the Constitution of the United States of America. According to the author, the model of American federalism was copied by the other countries, converging, in whole or in part, to a duality of

RC: 98469

Available in: https://www.nucleodoconhecimento.com.br/technology-en/inter- 
competencies, characterized by the coexistence of at least two constitutional spheres of autonomous power, acting on the same territory and the same population (MENICUCCI, 2019).

In Brazil, federalism started from the existence of a unit with centralized power, distributing it among several units (federated entities), without eliminating the central power. This power delegated to states and municipalities is constitutionally upslawed through federal, state and municipal legislation. A system of cooperative federalism, both for economic, social and cultural issues, through programs and joint financing, considered by Viana et al (2008) as "institutional flexibility", seeking intergovernmental cooperation to achieve common ends.

Barata (2004) it should be noted that there is no hierarchy in the federal organization, because each sphere of power corresponds to a determined competence, presupposing autonomy of the federated entities. Although the study of federalism goes through the examination of the specificities of each Federation, there are common characteristics that represent the foundations of the Federal State.

In the current historical context, in which national states have the preponderant role of promoting social well-being, there is a need for mutual collaboration between the spheres of government, in order to achieve social and economic objectives, resulting from the identification that the execution of certain public functions cannot be an exclusive or hegemonic attribution of any of the federated entities, division of competence, cooperation and common interests. This is the predominant model nowadays, called cooperative federalism (CURVINA, 2017).

In fact, the management of public policies is fundamental for the development of goals and actions in the socioeconomic sphere that aim at the collective well-being of the population, through cooperation in the three spheres of government through the construction of decision-making and planned processes (SOARES, 2018). These processes represent the "inherent dilemma between the direct negotiations of local

RC: 98469

Available in: https://www.nucleodoconhecimento.com.br/technology-en/inter- 
governments and the incentives promoted by the central ideats", arising from recurrent problems represented by decentralization and centralization (DOURADO; ELIAS, 2011, p. 206).

A permanent support of SUS management is the strengthening of interfederative bonds, necessary for the consolidation of the system. The Organic Health Law (Law 8.080/90) established new strategies and instruments for the consolidation of health care networks, valuing the construction of collaborative relationships between federated entities through COAP and strengthening the coordinating role of state managers and inter-management committees (BRASIL, 1990).

In fact, decentralization seeks to build intergovernmental relations in the implementation of public policies and reinforces the importance of dialogue between subnational governments and the national government in the conduct of health policy. In addition to producing significant changes in the institutional design in the governmental organization and in the social field with emphasis on communication and sharing of responsibility among federal entities in the political and financial management of local health systems, expanding coverage and favoring the population's access to health services and actions (MOREIRA; FERRÉ; ANDRADE, 2017).

It is indisputable that decentralization is against the financial and management asymmetry of government levels, in the organization and management of the heterogeneous and non-institutionally integrated service network with impacts arising from the emergence of various local and isolated systems of health services, as well as in the fragmentation and disorganization of services made available to the community (LEVCOVITZ et al, 2001; SANTOS et al, 2015). Another important point caused by the decentralization discussed by the authors is related to the distancing of government agencies responsible for health financing (PINAFO et al, 2020).

RC: 98469

Available in: https://www.nucleodoconhecimento.com.br/technology-en/inter- 
The relationship between decentralization, efficiency and equity is permeated by complex causalnetworks, however, existing evidence indicates that, in a continental country such as Brazil, consisting of spatial diversity, territorial inequalities, distribution, intermediation and control costs far outweigh the gains in resource management, distribution of goods and services achieved by the centralized administration (AFFONSO, 1985; LIMA et al, 2015).

In fact, the geographical concentration of services of greater complicity, the regional differences between populations and political-institutional conditions of federative entities in Brazil, there is a need and use of available resources, with sharing of responsibility between the management spheres, in order to reconcile conflicting interests of different regions, aiming at the construction of a cooperative and financial model in the provision of health services (LIMA et al, 2012).

\subsection{GOVERNANCE AND REGIONAL INTER-MANAGEMENT COMMISSIONS - CIR: CHANNEL OF NEGOTIATION AND DECISION BETWEEN MUNICIPAL MANAGERS AND THE STATE WITHIN THE HEALTH REGION}

The CIR/AL were established on August 22, 2011, and their rules define them as privileged instances of negotiation, articulation, proposition and agreement regarding the operational aspects of the SUS within the Health Region, respecting the definitions of the Bipartite Intermanagers Commission (CIB), constituting a permanent space for solidarity and cooperative co-management at the regional level, from the identification of a network of organized, integrated and resolutive health care services, ensuring the improvement and application of the principles of the SUS (COSEMS/AL, 2014).

Composed of the Municipal Secretaries of Health and the representation of the Secretary of State for Health, which has the prerogative to coordinate the process of

RC: 98469

Available in: https://www.nucleodoconhecimento.com.br/technology-en/inter- 
agreement, their decisions are taken by consensus, in accordance with the provisions established by the Pact for Health.

In the state of Alagoas, through the approval of the Regionalization Master Plan (PDR), the sanitary territorial design was redefined, reorganized into two Health Macroregions, subdivided into ten Sanitary Regions, being 06 (six) in the 1st Macroregion, based in Maceió, and 04 (four) in the 2nd Macro-region, with headquarters in the municipality of Arapiraca.

With the mission of managing the Regional Health Policy, based on the knowledge of the epidemiological and socioeconomic reality of the municipality, the territory and the region, the CIR coordinates the construction of the RAR, ensuring the population's access to health services, regulating, monitoring and evaluating the goals established for the municipalities.

Aiming to deepen the cooperative character of the intergovernmental relations established by the Pact for Health and to institutionalize, within the scope of SUS management, a set of management and care tools, Decree $7.508 / 2011$ brings the definition of health regions and health care networks, creates the health map, the National List of Health Actions and Services - RENASES the National List of Essential Medicines - RENAME, and COAP (BRASIL, 2011). It establishes the negotiation and intergovernmental articulation bodies that operate on various territorial scales (national, state and regional).

According to Habermasian theory, the effectiveness of perceived demands in the public sphere needs communication and dialogue flows, that is, a deliberative model of democracy. In the Republican conception, the public and political space and civil society as its infrastructure, are strategic points of democratic and communicative organization. Having the function of ensuring the integrative force and the democratic autonomy of the practice of understanding among the subjects (HABERMAS, 1995).

$\mathrm{RC}: 98469$

Available in: https://www.nucleodoconhecimento.com.br/technology-en/inter- 
Under strategic conditions, individuals make decisions that anticipate consequences of their actions, choose political institutions, in a word, act politically. And the way they act plays a decisive role in obtaining and maintaining democracy, in order to open paths that enable communication, contributing to the greater good, the right to health.

Habermas (1995) from the point of view of discursive theory, the democratic formation of the will is legitimized through decision-making and communicative assumptions, which allow through rationality the public use of the reason to dialogue with the population's health needs in order to guarantee fair and cooperative processes.

The good cooperative development occurred through the CIR, contributes to the articulation and regulation of actions within the territories through the shared negotiation assumed by the federated entities in a solidary perspective (Lima, 2012; Santos et al, 2014). Thus, the strengthening of governance in the health region can bring together what decentralization itself has fragmented and overcomes the challenges to organized care integration in health regions (LIMA et al, 2016).

Carvalho et al (1995) consider that, depending on what was established in the Federal Constitution, municipalities enjoy political and administrative autonomy to plan and manage their local health systems. Therefore, the only way for the Ministry and the State Health Secretariats to interfere in municipal management would be through agreements and contracts freely established between the parties.

In the words of Noronha et al (2008), the SUS "is part of a broad conception of the right to health and the role of the State in guaranteeing this right, incorporating in its institutional and decision-making structure, spaces and instruments for democratization and sharing of the management of the health system".

RC: 98469

Available in: https://www.nucleodoconhecimento.com.br/technology-en/inter- 
Given these characteristics and the federative model defined constitutionally in health, the strengthening of shared management and the instruments that can favor it, among them, is especially important.

The study allowed to reach several considerations about the theme, without intending to exhaust it, given the limitations imposed by the research cut out or even by the type of analysis proposed by the study.

\section{CONCLUSION}

Ensuring access to health services, seeking comprehensive care requires a systemic organization, coming from cooperative pacts within federative governance aiming at strengthening the organization of health regions. Having the CIR as an important organ in the coordination, organization and construction of the spaces of agreement with a view to reconstruction and social organization.

Institutional learning, the result of the dynamics of participation in the CIR, strengthens intermanagers management and presents itself as an important component for the construction of the regionalized network.

This research demonstrates that the regional comprehensive planning, the organization of actions and services, financing and regional governance are essential elements in the regionalization process, achieved through the deliberations of the CIR, as well as other points agreed in the meetings, as described in the resolutions, with the main focus on the provision of health services available to the population.

Cooperation tends to favor the municipalities that are part of a region, because it allows the optimization of resources, the solidary use of the means dispersed among the federated entities, and the guarantee of profitability for the municipalities with capacity to attend, leaving it clear that the CIR/AL are a true local space of agreement and interfederative articulation.

RC: 98469

Available in: https://www.nucleodoconhecimento.com.br/technology-en/inter- 


\section{REFERENCES}

AFFONSO, Rui de Brito Álvarez. SILVA, Pedro Luiz Barros. (Org). A federação em perspectiva: ensaios selecionados. São Paulo 10 (3) Edições Fundap; 1995 [acesso em 3 jul 2020]. Disponível em:https://www.seade.gov.br/wpcontent/uploads/2014/07/v10n3.pdf

ANDRADE, Laurielle de Souza.; FRANCISCHETTI, leda. Referência e contrarreferência compreensões e práticas. Sal. \& Transf. Soc. Florianópolis, v. 10, n. 1/2/3, p. 54-63. 2019 [acesso em 13 jul. 2021]. Disponível em: file:///C:/Users/nadja/Dropbox/My\%20PC\%20(LAPTOP-

EA4SVGFV)/Downloads/5281-22616-1-PB.pdf.

BARATA, Luiz Roberto Barradas. TANAKA, Oswaldo Yoshimi. MENDES, José Dínio Vaz. Por um processo de descentralização que consolide os princípios do Sistema Único de Saúde. Epidemiologia e Serviços de Saúde, Brasília, 13 (1) 1524. 2004 [acesso em 02 jun 2020]. Disponível em: http://scielo.iec.gov.br/pdf/ess/v13n1/v13n1a03.pdf

BRASIL. Conselho Nacional de Secretários de Saúde. Legislação Estruturante do SUS/CONASS. Brasília, 2011. 534. [acesso em 25 jul, 2020]. Disponível em: http://bvsms.saude.gov.br/bvs/publicacoes/para_entender_gestao_sus_v13.pdf

BRASIL. Constituição (1988). Constituição da República Federativa do Brasil. promulgada em 5 de outubro de 1988. Brasília, DF: Senado Federal;1988 [acesso $\begin{array}{lllll}\text { em } & 10 & \text { mai } & \text { 2020]. }\end{array}$ https://www2.senado.leg.br/bdsf/bitstream/handle/id/518231/CF88_Livro_EC91_201 6.pdf

BRASIL. Decreto n. 7.508, de 28 de junho de 2011. Regulamenta a Lei n. 8.080, de 19 de setembro de 1990, para dispor sobre a organização do Sistema único de Saúde - SUS, o planejamento da saúde, a assistência à saúde e a articulação

RC: 98469

Available in: https://www.nucleodoconhecimento.com.br/technology-en/inter- 
interfederativa, e dá outras providencias. Diário Oficial da União, Poder Executivo, Brasília, DF, 29 jun. 2011. Seção 1, p 1. [acesso em 10 fev 2020]. Disponível em http://www.planalto.gov.br/ccivil_03/_Ato2011-2014/2011/Decreto/D7508.htm.

BRASIL. Lei oํ 8.080, de 19 de setembro de 1990. Lei Orgânica da Saúde. Dispõe sobre as condições para a promoção, proteção e recuperação da saúde, a organização e o funcionamento dos serviços correspondentes e dá outras providências. Brasília, set. 1990. [acesso em 23 abri 2020]. Disponível em: http://www.planalto.gov.br/ccivil_03/leis/18080.htm

BRASIL. Ministério da Saúde. Portaria 4.279, de 30 de dezembro de 2010. Estabelece diretrizes para a organização da Rede de Atenção à Saúde no âmbito do Sistema Único de Saúde (SUS). Diário Oficial da União 31 dez. 2011[acesso em 27 jul 2020].

Disponível

em:

https://bvsms.saude.gov.br/bvs/saudelegis/gm/2010/prt4279_30_12_2010.html

BRASIL. Ministério da Saúde. Secretaria de Atenção à Saúde. Departamento de Regulação, Avaliação e Controle de Sistemas. Diretrizes para a programação pactuada e integrada da assistência à saúde. Brasília. 2006. [acesso em: 27 jul 2020].

Disponível

em: http://bvsms.saude.gov.br/bvs/publicacoes/DiretrizesProgPactuadalntegAssistSaude. pdf

BRASIL. Ministério da Saúde. Secretaria de Gestão e Participativa. Contrato Organizativo da Ação Pública da Saúde. Brasília. 2011 [cesso 30 jul 2020]. Disponível em: http://bvsms.saude.gov.br/bvs/publicacoes/contrato_organizativo_acao_publica_sau de.pdf

RC: 98469

Available in: https://www.nucleodoconhecimento.com.br/technology-en/inter- 
BRASIL. Resolução oo 1 setembro de 2011. Gabinete do Ministério da Saúde. Comissão Intergestores Tripartite. Brasília, [citado 07 Jul. 2020]. Disponível em: https://bvsms.saude.gov.br/bvs/saudelegis/cit/2011/res0001_29_09_2011.html

CARVALHO, Guido Ivan. SANTOS, Lenir. Comentários à lei orgânica da saúde: sistema único de saúde. São Paulo: Ed. Hucitec, 1995

CONSELHO DE SECRETÁRIOS MUNICIPAIS DE ALAGOAS. 0 papel dos gestores de saúde nas comissões Intergestores regionais. Maceió, 2014 $\begin{array}{llllll}\text { [acesso } & \mathrm{em} & 12 & \mathrm{abr} & 2020] & \text { Disponível em: }\end{array}$ http://www.cosemsal.org/old/public/documentos/manual-azul-o-papel-dos-gestoresde-saude.pdf

CURVINA, Ana Cristina Carvalho. A regionalização da saúde no federalismo brasileiro. Cad. Ibero-Amer. Dir. Sanit., Brasília, 6(2):42-57, abr./jun, 2017. [acesso em 13 fev 2020]. Disponível em: http://dx.doi.org/10.17566/ciads.v6i2.385

DOURADO, Daniel de Araújo.; ELIAS, Paulo Eduardo Mangeon. Regionalização e dinâmica política do federalismo sanitário brasileiro. Rev. Saúde Pública. São Paulo, v. 45, n. 1, p. 204-11. 2011. [acesso em 05 jul. 2021]. Disponível em: https://www.scielo.br/j/rsp/a/bCWB3sWTXQLXWjjFkcWwgLt/?format=pdf\&lang=pt

DUARTE, Ligia Schiavon.; MENDES, Áquilas Nogueira.; LOUVISONA, Marília, Cristina Prado. O processo de regionalização do SUS e a autonomia municipal no uso dos recursos financeiros: uma análise do estado de São Paulo (2009-2014). Saúde Debate, Rio de Janeiro, v. 42, n. 116, p. 25-37. 2018. [acesso em 10 jul 2020].

https://www.scielo.br/j/sdeb/a/gcPyhjjWdrqZcG9V4nYhPBd/?format=pdf\&lang=pt.

HABERMAS, Jurgen. Três Modelos Normativos de Democracia. Cadernos da Escola do Legislativo, Belo Horizonte, 3 (3)105-122, jan.jun., 1995.

RC: 98469

Available in: https://www.nucleodoconhecimento.com.br/technology-en/inter- 
LEVCOVITZ, Eduardo. LIMA, Luciana Dias de. MACHADO, Cristiane. Vieira. Política de saúde nos anos 90: relações intergovernamentais e o papel das Normas Operacionais Básica. Ciência e Saúde Coletiva, Rio de Janeiro, 6, (2) 269-291, 2001 [acesso em 10 jul 2020]. Disponível em: https://www.scielo.br/pdf/csc/v6n2/7003.pdf.

LIMA, Luciana Dias de. et al. Regionalização e acesso à saúde nos estados brasileiros: condicionantes históricos e político-institucionais. Ciência e Saúde Coletiva, Rio de Janeiro, 17 (11) 2881-2892, 2012 [acesso 10 jun 2020]. Disponível em: https://www.scielo.br/pdf/csc/v17n11/v17n11a04.pdf

LIMA, Luciana Dias de.; ALBUQUERQUE, Mariana Vercesi.; SCATENA, João Henrique Gurtler. Quem governa e como se governam as regiões e redes de atenção à saúde no Brasil? Contribuições para o estudo da governança regional na saúde. Novos Caminhos, n. 8. 2016. [acesso em 29 fev 2020]. Disponível: https://www.resbr.net.br/wp-content/uploads/2016/02/Novos-Caminhos-8.pdf.

LIMA, Luciana Dias de. et al. Descentralização e regionalização: dinâmica e condicionamento da implantação do pacto pela saúde no Brasil. Ciência \& Saúde Coletiva, n. 17, v. 7, p. 1903-1914, 2012. [acesso em 29 fev. 2020]. Disponível em: https://www.scielo.br/j/csc/a/FyqLwWmbv8WQs8BPW8scpTt/?lang=pt

MENICUCCI, Telma Maria Gonçalves. Regionalização no federalismo brasileiro. Cad. Saúde Pública 2019; 35 Sup 2: e00078419. [acesso em 29 fev 2020]. Disponível: https://www.scielosp.org/article/csp/2019.v35suppl2/e00078419/pt/

MINAYO, Maria Cecília de Souza. O desafio do conhecimento. Pesquisa qualitativa em saúde; $12^{\underline{a}}$ ed; São Paulo. Hucitec. 2010. 407p. ISBN 978-85-271-0181-3.

MOREIRA, Laura Monteiro de.; FERRÉ, Felipe.; ANDRADE, Eli lola Gurgel. Financiamento, descentralização e regionalização: transferências federais e as redes de atenção em Minas Gerais, Brasil. Ciência \& Saúde Coletiva, n 22, v. 4, p.

$\mathrm{RC}: 98469$

Available in: https://www.nucleodoconhecimento.com.br/technology-en/inter- 
1245-1256, 2017. [acesso em 21 ago 2021]. Disponível em: https://www.scielosp.org/pdf/csc/2017.v22n4/1245-1256/pt.

NORONHA, José Carvalho de. LIMA, Luciana. Dias de. MACHADO, Cristiane Vieira. O Sistema Único de Saúde: SUS. In: Giovanella L. et al. (Org.). Políticas e sistemas de saúde no Brasil. Rio de Janeiro: Fiocruz, 2008. p. 365-394.

PINAFO, Elisangela. et al. Problemas e estratégias de gestão do SUS: a vulnerabilidade dos municípios de pequeno porte. Ciência \& Saúde Coletiva, n2. 25, v. 5, p. 1619-1628, 2020 [acesso em 21 ago 2021]. Disponível em: https://scielosp.org/pdf/csc/2020.v25n5/1619-1628/pt

SANTOS, Adriano Maia dos. GIOVANELLA, Ligia. Governança regional: estratégias e disputas para gestão em saúde. Revista de Saúde Pública, São Paulo, 48 (4) 622-631, 2014[acesso em 10 jun 2020]. Disponível em: https://www.resbr.net.br/wpcontent/uploads/historico/governan\%C3\%A7a_regional.pdf

SANTOS, Lenir. CAMPOS, Gastão Wagner de Souza. SUS Brasil: a região de saúde como caminho saúde e Sociedade, São Paulo, 24 (2) 438-446, 2015 [acesso em 10 jul 2020]. Disponível em: https://www.scielo.br/pdf/sausoc/v24n2/0104-1290-sausoc-24-02-00438.pdf

SANTOS, Lenir. Região de saúde e suas redes de atenção: modelo organizativosistêmico do SUS. Ciência \& Saúde Coletiva, 22(4):1281-1289, 2017. [acesso em 29 jul, 2020]. Disponível em: https://www.scielosp.org/pdf/csc/2017.v22n4/1281$1289 / p t$

SOARES, Marcia Miranda. MACHADO, José Ângelo. Federalismo e políticas públicas. Brasília: Enap, 2018. 112. [acesso em: 29 fev 2020]. ISBN: 978-85-2560081-3Disponível em: https://repositorio.enap.gov.br/bitstream/1/3331/1/Livro_Federalismo\%20e\%20Pol\% C3\%ADticas\%20P\%C3\%BAblicas.pdf.

$\mathrm{RC}: 98469$

Available in: https://www.nucleodoconhecimento.com.br/technology-en/inter- 
VIANA, Ana Luiza D'Ávila. LIMA, Luciana Dias. OLIVEIRA, Roberta. Gondim de. Descentralização e federalismo: a política de saúde em novo contexto - lições do caso brasileiro. Ciência e Saúde coletiva. 2002 Jul; 7 (3):493-507. [acesso em 5 mai 2020]. Disponível em: https://www.scielo.br/pdf/csc/v7n3/13027.pdf

VIANA, Ana Luiza D' Ávila. et al. Novas Perspectivas para a regionalização da saúde; São Paulo em perspectiva, 22 (1) 92-106, jan/jun.2008 [acesso em 7 jun 2020].

http://produtos.seade.gov.br/produtos/spp/v22n01/v22n01_07.pdf

WAGNER, Gastão. Efeitos paradoxais da descentralização do Sistema Único de Saúde do Brasil; In: Fleury S. (Org.). Democracia, descentralização e desenvo/vimento: Brasil e Espanha. Rio de Janeiro: FGV, 2006. 417-442. Disponível em https://www.scielo.br/pdf/csc/v17n11/v17n11a04.pdf.

Posted: March, 2021.

Approved: September, 2021.

RC: 98469

Available in: https://www.nucleodoconhecimento.com.br/technology-en/inter- 